\title{
ANALYSIS INFLUENCE OF DIFFERENCE PERCEPTION BETWEEN SHARI'A BANKING WITH CONSUMER PERCEPTION TOWARDS CUSTOMER'S PURCHASE INTENSION SHARI'A BANKING IN SEMARANG - INDONESIA
}

\author{
Sri Rahayu Tri Astuti ${ }^{1}$
}

\begin{abstract}
* Affiliation:
${ }^{1}$ Faculty of Economica \& Business - Management Department

Diponegoro University Semarang Indonesia Jl. Prof. Soedharto, SH, Tembalang (Gedung A) Semarang - Indonesia email :

sr.triastuti73@gmail.com srirahayutri@undip.ac.id
\end{abstract}

\begin{abstract}
:
Based onShari'a Banking's development background in Indonesia such as phylosophy aspects, legal aspectsalso prospect and potential aspects,Shari'a Banking's development should increase significantly. Instead of expectation, at the beginning year 2015,Shari'a Banking has decreased 1,6\% inCentral Java (Jawa Tengah).

This research aims to analyze influence of difference perception betweenShari'a Bankingwith consumer perception toward customer's purchase intentionShari'a Bankingin Semarang. This research use qualitative analysis methode with 30 respondents and this research gains : (1) Respondents understand and have purchase intensionShari'a Bankingare 20 respondents; (2) Respondents understandbut do not have purchase intension Shari'a Bankingare 4 respondents; (3) Respondentsdo not understand anddo not have purchase intension Shari'a Banking are 6 respondents.

Keywords : Consumer Perception, Purchase Intension, Shari'a Banking.
\end{abstract}

\section{INTRODUCTION}

There are three background of Shari'a Banking development in Indonesia (according to Shari'a Banking Development of Bank Indonesia,dpbs@bi.go.id, 2012). There are : (1) Phylosophy Aspects, (2) Legal Aspects and (3) Potential and Prospect Aspects. First, Phylosophy Aspects. Phylosophy Aspects such as Islamic Economics Values and National Herritages. At Islamic Economics Values such as: tauhid (believe in God); syariah (Islam); akhlak (morals); ukhuwah (relationship with God \& society); adil (fair); seimbang (balance), maslahat (usefull) and falah. National Herritages such as : people that believe in one God; has great moral hazzard; unity in diversity and working together; deliberation for consensus andsocial justice for all Indonesian's people.

Second is Legal Aspects, legal Aspects are UU No.7/1992 and replace with UU No. 10/1998 : Banking System (Perbankan) : 
dual banking system dan dual system banking.; UU No.23/1999 and replace with UU No.6/2009 about Bank Indonesia : Controlling Monetery Banking based on Shari'a Principle and Indonesian Bank, can be done by give fund based on Shari'a Principle to the Bank to solve short time funding problem.And UU No.21/ 2008 about Shari'a Banking System.

The last aspects is Potential and Prospects Aspects. Potential and Prospects Aspects, consist of Domestic Market and Global Market.

\section{Domestic Market}

- $\quad$ Large population (over 200 millions people); large potensial natural resources; Indonesia has great prospect in economics development and financial shari'a.

- Socio-cultural's Indonesian society (gotong royong) is seen in line with value ofeconomics system and financial shari'a.

- Development and Growth market money has increase, specially shari'a national banking.

- Shari'a Banking as financial industry based on real sector is matching with economics condition in Indonesia.

\section{Global Market}

- Over 1.3 millions moslem people in the world are represent $20 \%$ world population and have total contribution approaching 10\% world GNP (Gross National Product).

- Moslem's natural resources dominate the world's natural resources potensial.

- InternationalShari'a Banking has increased fast, including at non moslem's country, such as England and Europe.

- More than 300 Islamic financial institutions in more than 75 countries manage assets about USD 700 - 1000 billions, use developing shari'a financial instruments.

Base on that background, Shari'a Banking's development should be increase, but the conditions are not as we expected. There are several articles that publish these conditions such as : "The Growth of Shari'a Banking's Development is Slowing Down in 2014" (Kompas, December 13, 2013); "Market Share of Shari'a Banking has decreased from 4.85\% at the end of 2014 being $4.67 \%$ at the beginning of 2015 until May 2015". The growth ofShari'a Banking in Central Java (Jawa Tengah) has similary conditions with the growth ofShari'a Banking in Indonesia. "The growth of Shari'a Banking in Central Java has decreased 1.6\% at the first 5 months at the beginning of 2015" (Humas Jateng, August 21, 2015).Wijonarko, Hermawan Endro said that "The Growth of Shari'a Banking in Central Java is Slowing Down. (Tribun Jateng, August 13, 2015). For more details can be read in the following Table below. 
Table 1. The Source, Date of Publication and Title of the Articles about the Growth of Shari'a Banking's Development

\begin{tabular}{|c|c|c|c|}
\hline No. & The Source & Date of Publication & Title of Articles \\
\hline 1 & $\begin{array}{l}\text { Kompas - Suryowati, } \\
\text { Estu }\end{array}$ & December 13, 2013 & $\begin{array}{l}\text { The Growth of Shari'a Banking's } \\
\text { Development is Slowing Down in } \\
2014\end{array}$ \\
\hline 2 & Fuad, Hafid & May 23,2015 & $\begin{array}{l}\text { The Growth ofShari'a Banking's } \\
\text { Development Slowed Left by Parent } \\
\text { Business. }\end{array}$ \\
\hline 3 & $\begin{array}{l}\text { Kompas.com - } \\
\text { Sukmana, Yoga }\end{array}$ & June 01,2015 & $\begin{array}{l}\text { Impact toShari'a Banking because } \\
\text { The Economy Slowed Down. }\end{array}$ \\
\hline 4 & $\begin{array}{l}\text { Tribun Jateng.com - } \\
\text { Wijonarko, Hermawan } \\
\text { Endra }\end{array}$ & August 13, 2015 & $\begin{array}{l}\text { Growth of Shari'a Banking in Cental } \\
\text { Java (Jateng) Slowed }\end{array}$ \\
\hline 5 & $\begin{array}{l}\text { Suara Merdeka.com - } \\
\text { Puspita, Anggun }\end{array}$ & August 14, 2015 & $\begin{array}{l}\text { Growth of Shari'a Banking hasn't } \\
\text { Optimal }\end{array}$ \\
\hline 6 & Tribun Jateng & August 20, 2015 & $\begin{array}{l}\text { Aris sure that Shari'a Banking will } \\
\text { grow. By } 2015 \text {, Shari'a Commercial } \\
\text { Bankinggrow only } 1 \text { unit. Market } \\
\text { Share of Shari'a Banking has } \\
\text { decreased from } 4.85 \% \text { at the end of } \\
2014 \text { and being } 4.67 \% \text { at the beginning } \\
\text { of } 2015 \text { until May } 2015 \text { ". }\end{array}$ \\
\hline 7 & Humas Jateng & August 21, 2015 & $\begin{array}{l}\text { At the beginning in } 2015 \text {, the growth } \\
\text { of Shari'a Banking were down } 1.6 \%\end{array}$ \\
\hline
\end{tabular}

Source : the data is processed, 2015

Besides of Table 1 above, the data of theShari'a Banking Statistics per June 2015 shows a growing number of Syariah Commercial Banking also less pleasant developments such as seen in the following table.

Table 2. Shari'a Banking Statistic per June 2015

\begin{tabular}{|l|c|c|c|c|c|c|c|}
\hline \multirow{2}{*}{ Description } & \multicolumn{7}{|c|}{ Year } \\
\cline { 2 - 8 } & $\mathbf{2 0 0 9}$ & $\mathbf{2 0 1 0}$ & $\mathbf{2 0 1 1}$ & $\mathbf{2 0 1 2}$ & $\mathbf{2 0 1 3}$ & $\begin{array}{c}\text { July } \\
\mathbf{2 0 1 4}\end{array}$ & $\begin{array}{c}\text { June } \\
\mathbf{2 0 1 5}\end{array}$ \\
\hline $\begin{array}{l}\text { Amount of Syariah Commercial } \\
\text { Banking }\end{array}$ & 6 & 11 & 11 & 11 & 11 & 12 & 12 \\
\hline
\end{tabular}

Source: SBS, Juni 2015 
From the table above, we know that growing number of Syariah Commercial Banking (SCB) also less pleasant development. At 2009, amount of Syariah Commercial Banking is 6 and amount of SCB from 2010 till June 2014 is 11. Start July 2014, amount of SCB has increased only $1 \mathrm{SCB}$.

Based on fenomena gap and data above, encourage author to research about Analyze Influence Of Difference Perception Between Shari'a BankingWith Consumer Perception Toward Customer's Purchase Intention Shari'a BankingIn Semarang - Indonesia. Sometimes promotion tools fromShari'a Banking are not right on target because of the difference perception betweenShari'a Banking with consumer perseption, so it can influence customer's purchase intension Shari'a Banking. Where as the problem formulation in this research is whether difference perception betweenShari'a Banking with consumer perception can affect customer's purchase intension Shari'a Banking.

\section{LITERATUR REVIEW}

\begin{tabular}{|c|c|c|}
\hline \multicolumn{3}{|c|}{$\begin{array}{l}\text { Shari’a Banking's Development Background in Indonesia : } \\
\text { Philosophy Aspects; Legal Aspects and Potensial and Prospect Aspects }\end{array}$} \\
\hline \multicolumn{3}{|c|}{ Data Source : Based on Articles and Shari'a Banking Statistic } \\
\hline \multicolumn{3}{|c|}{$\begin{array}{l}\text { The Problem Formulation In This Research Is Whether Difference Perception Between } \\
\text { Shari'a Banking With Consumer Perception Can Affect Customer's Purchase Intension Shari'a Banking? }\end{array}$} \\
\hline \multicolumn{3}{|c|}{ Difference Perception Between Shari'a Banking With Consumer Perception } \\
\hline \multicolumn{3}{|l|}{ Shari'a Banking Perception } \\
\hline \multicolumn{3}{|c|}{ Influence Customer's Purchase Intension Shari'a Banking } \\
\hline Positif (+) & or & Negatif (-) \\
\hline \multicolumn{3}{|c|}{ Results } \\
\hline $\begin{array}{l}\text { (1) Understand \& Has Purchase } \\
\text { Intension }\end{array}$ & $\begin{array}{l}\text { (2) Understand But Has No } \\
\text { Purchase Intension }\end{array}$ & $\begin{array}{l}\text { (3) Not Understand \& Has } \\
\text { Not Purchase Intension }\end{array}$ \\
\hline
\end{tabular}

Figure 1. Road Map of the Research

\section{Definition of Perception}

William J. Stanton in Setiadi, Nugroho J. (2003) said :"Perception can be defined by past experiences, stimuli that we receive through sensory perception". Schiffman \& Kanuk in Nitisusastro, Mulyadi (2012) said that "Perception is described as the process by which an individual select, organizes and translates into a coherent sense of stimulation with all the happening in the world. Perception can be described as how we see the world around us".

Nitisusastro, Mulyadi (2012) said : "There are individual internal factors that influence customer behaviour such as perception, motivation, learning, personality and attitude. So perception is one of the individual internal factors that influence customer behaviour such as 
introduction to the issue, information retrival, evaluation of alternatives, purchasing decision and postpurchase behaviour."

\section{Definition of Purchase Intension}

Kotler, Philip \& Armstrong, Gary (2008) said that purchase intension is a decision to buy a brand among a variety of other brands. Ferdinand, Augusty (2013) said that there are three indicators of purchase intension, such as : intensity of the search information, interest in becoming a customer's Shari'a Banking and preferential intension.

\section{Definition of Shari'a Banking.}

Shari'a Banking is defined as its implementation based on Islamic law or shari'a. Because Shari'a Banking based by Islamic's Law so Shari'a Banking does not have interest rate, because it considered usury (riba) and sin. In the Shari'a Banking system, we know about Nisbah (the ratio of the process is equally known to) and proved by the bank's client party. (Abadi, Rizki, June 09, 2015).

\section{Journals Supporting Research}

There are three journals supporting research :

1. Astuti, Tri \& Mustikawati, Rr. Indah :Influence of Consumer's Perception : Interest Rate, Promotion and Service Quality towards Purchase Intension at Bank. Jurnal Nomina1/Volume II Nomor 1/2013.

2. Maski, Ghozali. Analysis Purchase Decision: Component and Logistic Model Approach. Study in Shari'a Banking in Malang. Journal of Indonesian Applied Economics, Vol. 4 No. 1 Mei 2010. 43 - 57

3. Mu'allim, Amir. Customer Perception to Shari'a Financial Institusion. Al-Mawarid Edisi X tahun 2003.

\section{METHOD}

This research use qualitatif methode, because we focus directly on the problem of human life. (Danim, Sudarwan, 2002). Qualitative data collection was done by means of semi structured interview. It means that we interview respondents with asking questions that focus in special or general topics andcreate a detailed interview guide. Amount of respondents in this research are 30 Respondents.

\section{FINDING AND DISCUSSIONS}

\section{Respondents's Demographic Datain Table}

Table 3Respondents's Gender

\begin{tabular}{|c|c|c|c|}
\hline \multirow{2}{*}{ No. } & \multicolumn{2}{|c|}{ Respondents'sGender } & \multirow{2}{*}{ Amount } \\
\cline { 2 - 3 } & Male & Female & \\
\hline Amount & 14 & 16 & 30 \\
\hline
\end{tabular}


Table 4 Age of Respondents

\begin{tabular}{|c|l|c|}
\hline No & \multicolumn{1}{|c|}{ Age (In Year) } & Amount \\
\hline 1 & $20--25$ & 17 \\
\hline 2 & $26-30$ & 8 \\
\hline 3 & $31-35$ & 3 \\
\hline 4 & $>35$ & 2 \\
\hline & Amount & $\mathbf{3 0}$ \\
\hline
\end{tabular}

Table 5 Marital Status of Respondents

\begin{tabular}{|c|c|c|}
\hline \multicolumn{2}{|c|}{ Marital Statusof Respondents } & \multirow{2}{*}{ Amount } \\
\cline { 1 - 2 } Single & Married & \\
\hline 24 & 6 & 30 \\
\hline
\end{tabular}

Table 6 Religion of Respondents

\begin{tabular}{|c|c|c|}
\hline No & Religion & Amount \\
\hline 1 & Islam & 25 \\
\hline 2 & Katholik & 3 \\
\hline 3 & Kristen Protestan & 2 \\
\hline & Amount & $\mathbf{3 0}$ \\
\hline
\end{tabular}

Table 7 Last Education of Respondents

\begin{tabular}{|c|c|c|}
\hline No & Last Education & Amount \\
\hline 1 & S1 & 30 \\
\hline
\end{tabular}

Table 8 Job Type of Respondents

\begin{tabular}{|c|l|c|}
\hline No & \multicolumn{1}{|c|}{ Job Type } & Amount \\
\hline 1 & Entrepreneurial & 5 \\
\hline 2 & Employees of BUMN & 7 \\
\hline 3 & Private Employees & 5 \\
\hline 4 & $\begin{array}{l}\text { Others (Teacher, Foundation } \\
\text { Staf, Freelancer, Student, } \\
\text { Pharmacists) }\end{array}$ & 13 \\
\hline & \multicolumn{1}{|c|}{ Amount } & $\mathbf{3 0}$ \\
\hline
\end{tabular}

Table 9 Job Field of Respondents

\begin{tabular}{|c|l|c|}
\hline No & Job Fieldof Respondent & Amount \\
\hline 1 & Economy/Trader & 15 \\
\hline 2 & Educators & 2 \\
\hline 3 & Banking & 3 \\
\hline 4 & Others:Investor,Services,Pharmacists & 10 \\
\hline & Amount & $\mathbf{3 0}$ \\
\hline
\end{tabular}


Table 10 Earning per Month of Respondents

\begin{tabular}{|c|c|c|}
\hline No & Earning Per Month & Amount \\
\hline 1 & $\mathrm{Rp} \mathrm{2.500.000,-} \mathrm{s/d} \mathrm{Rp} \mathrm{4.000.000,-}$ & 19 \\
\hline 2 & Rp 4.000.001,-- s/d Rp 5.500.000,- & 3 \\
\hline 3 & Rp 5.500.001,- s/d Rp 7.000.000,- & 0 \\
\hline 4 & >Rp. 7.000.000,- & 8 \\
\hline & Amount & $\mathbf{3 0}$ \\
\hline
\end{tabular}

Table 11 Average Consumption Each Day of Respondents

\begin{tabular}{|c|c|c|}
\hline No & Average Consumption Each Day & Amount \\
\hline 1 & Rp. 50.001,- s/d Rp. 100.000,- & 22 \\
\hline 2 & Rp. 100.001 s/d Rp. 150.000,- & 4 \\
\hline 3 & Rp. 150.000,- s/d Rp 200.000,- & 2 \\
\hline 4 & > Rp. $200.000,-$ & 2 \\
\hline & Amount & 30 \\
\hline
\end{tabular}

\section{Questionnaire}

Table 12 Summary of The Respondents's Answer

\begin{tabular}{|c|c|c|c|c|}
\hline \multirow{2}{*}{ No } & \multirow{2}{*}{ Questionnaire } & \multicolumn{2}{|c|}{ Answer } & \multirow{2}{*}{ Description } \\
\hline & & Yes & No & \\
\hline 1 & $\begin{array}{l}\text { Easy to Understand } \\
\text { Shari'a Banking's Terms }\end{array}$ & 9 & 21 & $\begin{array}{l}\text { Most of Respondents do not understand with } \\
\text { many foreign terms because they use foreign } \\
\text { language (Arabic). }\end{array}$ \\
\hline 2 & $\begin{array}{l}\text { Perception of Shari'a } \\
\text { Bankingis in compliance } \\
\text { with the initial perception } \\
\text { of respondents. }\end{array}$ & 17 & 23 & $\begin{array}{l}\text { There are respondents assume that Shari'a Banking } \\
\text { has same system with Convensional Banking. They } \\
\text { said that Shari'a Banking less detail explanation } \\
\text { about their specialty. } \\
\text { Although there are different opinions. }\end{array}$ \\
\hline 3 & $\begin{array}{l}\text { Respondent has } \\
\text { Purchase Intension }\end{array}$ & 22 & 8 & $\begin{array}{l}\text { There are some reasons why respondent has purchase } \\
\text { intension: Because most of them are moslem and for } \\
\text { hajj savings. } \\
\text { The other reasons are : less administration fee, } \\
\text { good services quality, less lining up because of less } \\
\text { customers. }\end{array}$ \\
\hline 4 & $\begin{array}{l}\text { Shari'a Banking is in } \\
\text { compliance with the } \\
\text { principle of Shari'a }\end{array}$ & 13 & 17 & $\begin{array}{l}\text { Most of respondents assume that Shari'a Banking's } \\
\text { is not compliance with Principle of Shari'a, because } \\
\text { they assume that Shari'a Product is the same with } \\
\text { conventional bank, only different in term. }\end{array}$ \\
\hline
\end{tabular}


Table 13 Research Summary

\begin{tabular}{|c|l|c|}
\hline No & \multicolumn{1}{|c|}{ Summary } & Amount \\
\hline 1 & Respondents understand and have purchase intension Shari'a Banking & 20 \\
\hline 2 & $\begin{array}{l}\text { Respondents understand but do not have purchase intension Shari'a } \\
\text { Banking }\end{array}$ & 4 \\
\hline 3 & $\begin{array}{l}\text { Respondents do not understand and donot have purchase intension } \\
\text { Shari'a Banking }\end{array}$ & 6 \\
\hline & Amount & $\mathbf{3 0}$ \\
\hline
\end{tabular}

\section{CONCLUSION AND RECOMMENDATIONS Conclusion}

Conclusions from this research are :

1. Most of Respondents do not understand with many foreign termsbecause Shari'a Banking mostly use foreign language (Arabic).

2. There are respondents assume that Shari'a Banking has same system with Convensional Banking. They said that Shari'a Banking less detail explanation about their specialty.

3. There are some reasons why respondent has purchase intension : Because most of them are moslem and for hajj savings. The other reasons are : less administration fee, good services quality, less lining up because of less customers.

4. Most of respondents assume that Shari'a Banking's is not compliance with Principle of Shari'a, because they assume that Shari'a Productsare the same with Conventional Banking, only different in term.

\section{Recommendations}

Recommendations for this research are :

1. Shari's Banking should use terms other than Arabic (an universal terms) to gain non moslem's customer so it can change customer mindset that Shari'a Bank is not just for Moslems but also for the general public.

2. Shari'a Banking should have a distinguishing factor as compared to Conventional Banking, such as set the overall shari'a principles. It aims to remove the stigma that Shari'a Banking only different terms with Conventional Banking.

3. Shari'a Banking should improve education to consumers through conventional media and social media. Shari'a Banking can set the target market from various background's consumers, such as : students, university, housewives community and government or private institutions

4. Shari'a Banking should improve introduction Shari'a Banking's products through talkshows, personal sellings, roadshows, conferences or training to all Shari'a Banking's target market. It aims to change the mindset of people to use Shari'a Banking's products.

5. Shari'a Banking should give ease, promotion and network improvement to access Shari'a Banking's products. It aims to improve purchase intension Shari'a Banking.

6. Shari'a Banking should have better human resources'sselection process to get qualified human resources, so they more expert both theorical and practise in Shari'a Banking. 


\section{REFERENCES}

Abadi, Rizki. 09 June 2015. Sejarah dan Perkembangan Bank Syariah di Indonesia. Accessed date : 03.09.2015.

Astuti, Tri \& Mustikawati, Rr. Indah. 2013. Pengaruh Persepsi Nasabah tentang Tingkat Suku Bunga, Promosi dan Kualitas Pelayanan Terhadap Minat Menabung Nasabah. Jurnal Nominal/Volume II Nomor I /2013.

Danim, Sudarwan. Desember 2002. Menjadi Peneliti Kualitatif. CV Pustaka Setia.

Departemen Perbankan Syariah Bank Indonesia. dpbs@bi.go.id. 2012. (Shari’a Banking Development of Bank Indonesia, 2012).Kebijakan Pengembangan Perbankan Syariah di Indonesia.

Ferdinand, Augusty. 2013. Metode Penelitian Manajemen:Pedoman Penelitian untuk Penulisan Skripsi, Tesis dan Disertasi Ilmu Manajemen. Undip Press.

Fuad, Hafid. 23 Mei 2015. Pertumbuhan Bank Syariah Melambat Ditinggal Induk Usaha. Accessed date : 03.09.2015.

Humas Jateng. 21 Agustus 2015. Awal 2015, Pertumbuhan Bank Syariah Turun 1,6 persen. birohumas.jatengprov.go.id. Accessed date : 24.08.2015.

Kotler, Philip \& Armstrong, Gary. 2008. Prinsip - Prinsip Pemasaran, Edisi 12, Jilid 1. Penerbit Erlangga.

Maski, Ghozali. 2010. Analisis Keputusan Nasabah Menabung : Pendekatan Komponen dan Model Logistik Studi pada Bank Syariah di Malang. Journal of Indonesian Applied Economics. Vol. 4. No. 1 Mei 2010.

Mu'allim, Amir. 2003. Persepsi Masyarakat Terhadap Lembaga Keuangan Syariah. AlMawarid Edisi X Tahun 2003.

Nitisusastro, Mulyadi. September 2010. Perilaku Konsumen dalam Perspektif Kewirausahaan. Alfabeta Bandung.

Puspita, Anggun. 14 Agustus 2015. Pertumbuhan Perbankan Syariah Belum Optimal. berita. suaramerdeka.com. Accessed date : 26.09.2015

Setiadi, Nugroho J.. 2003. Perilaku Konsumen: Konsep dan Implikasi untuk Strategi dan Penelitian Pemasaran.

Sukmana, Yoga. 01 Juni 2015. Ekonomi Melambat, Industri Perbankan Syariah Kena Imbas. www.kompas.com /.Accessed date : 24.08.2015

Suryowati, Estu. 13 Desember 2013. Pertumbuhan Perbankan Syariah Melambat di 2014. www.kompas.com/. Accessed date : 03.09.2015.

UU No.7/1992dan diganti dengan UU No. 10/1998 : Perbankan

UU No.23/1999 dan diganti dengan UU No.6/2009 : Bank Indonesia

UU No.21/2008 : Perbankan Syariah.

Wijonarko, Hermawan Endro. 13 Agustus 2015. Pertumbuhan Perbankan Syariah di Jateng Melambat. jateng.tribunnews.com/. Accessed date : 24.08.2015. 